\author{
E.A. Ruziyeva ${ }^{1}$, A.M. Nurgaliyeva ${ }^{2, *}$, Z.K.Yessymkhanova ${ }^{3}$, L.A. Chaykovskaya ${ }^{4}$ \\ ${ }^{1,2}$ Narxoz University, ${ }^{3}$ Turan-Astana University, Kazakhstan, \\ ${ }^{4}$ Plekhanov Russian University of Economics, Russian Federation \\ lelvira.ruzieva@narxoz.kz, ªliya.nurgalieva@narxoz.kz,'3z.yesymkhanova@gmail.com, ${ }^{4}$ chaykovskaya.1.a@mail.ru \\ ${ }^{1}$ https://orcid.org/0000-0001-9120-7776, ${ }^{2}$ http:// orcid.org/0000-0001-6044-6926, \\ ${ }^{3}$ http:// orcid.org/0000-0001-5552-5849, ${ }^{4}$ https://orcid.org/0000-0002-1292-402X \\ ${ }^{1}$ Scopus Author ID: 56070067800, ${ }^{2}$ Scopus Author ID: 559334946000 , \\ ${ }^{3}$ Scopus Author ID: 5721169657, ${ }^{4}$ Scopus Author ID: 57192888110 \\ ${ }^{I}$ ResearcherID Y-6397-2018, ${ }^{2}$ Researcher ID: Y-2788-2018, ${ }^{3}$ Researcher ID: P-7337-2014, ${ }^{4} G-7275-2017$
}

\title{
Modeling and analysis of the mutual influence of the RUB / KZT and USD / KZT exchange rates: the period before the pandemic and as a result of the impact of COVID-19
}

\begin{abstract}
Object: to assess of the interdependence and mutual influence of the exchange rates of the RUB and USD against the tenge before the COVID-19 and during the period of its impact on the Kazakhstan`s financial market.

Methods: the main research methods are regression modeling, the least squares method, analysis and generalization of methodological approaches of authors assessed the influence of various factors on the exchange rates of countries.

Findings: the COVID-19 introduced uncertainty in the formation of exchange rates of the RUB / KZT and USD / KZT. The strong direct relationship between the RUB / KZT and USD / KZT, which existed before the pandemic, as a result of the impact of COVID-19, was replaced by a negative and weaker correlation dependence.

Conclusions: the impact of the pandemic on the exchange rates of the ruble against the tenge and the dollar against the tenge is ambiguous, which reduces the degree of mutual influence of exchange cross-rates between the ruble and the US dollar even in countries that closely interact with each other. Further research is required to identify the factors that contributed to this change in the interdependence of the ruble / tenge and dollar / tenge.
\end{abstract}

Keywords: exchange rate, rate correlation, forecast intervals, pandemic, regression analysis, exchange rate volatility, rate elasticity.

\section{Introduction}

At present, the exchange rate is one of the fundamental factors indicating the state of the financial market, the country's competitiveness, and the financial security of the state. That is why the problems of currency regulation are becoming central and riveting the attention of both government bodies and financial market participants in general.

Strengthening the integration processes in the world financial market has led to an increase in the importance of the influence of external factors on the foreign exchange market of Kazakhstan: world prices for energy resources, investor expectations, volatility of world currencies. The instability of the world financial system, exposure to the influence of many external factors requires research into the issues of exchange rate volatility in Kazakhstan.

Since Russia remains one of the main strategic and trading partners of Kazakhstan, changes affecting the Russian market are directly reflected in our country, which also affects the formation of the exchange rate of the tenge against the Russian ruble. Moreover, it should be borne in mind that both countries are influenced by the same external factors, for example, oil prices, foreign policy, dependence on the US dollar. Of course, we are not talking about a one hundred percent correlation between the Russian ruble and the Kazakhstani tenge. However, a close connection can still be traced.

Since the tenge is closely dependent on the US dollar, it becomes necessary to study the relationship and the degree of influence of American financial policy on the exchange rate of the Kazakh national currency. This need is also intensified due to the fact that the pandemic had a significant impact on the development of the economies of all countries of the world, since the exchange rate ultimately has a significant impact on macroeconomic indicators: from inflation to the balance of payments. As a result of this influence, it

\footnotetext{
${ }^{*}$ Corresponding author.

E-mail address: aliya.nurgalieva@narxoz.kz
} 
becomes necessary to study the positions of the tenge against the US dollar and the Russian ruble in terms of a new degree of influence.

Hypothesis 1: if we consider the tenge as the base of assessment, then based on the study of the correlation between the tenge and the ruble and the tenge against the US dollar, it is possible to assess the degree of interdependence of the RUB / KZT and USD / KZT exchange rates.

Hypothesis 2: the presence of a relationship between exchange rates allows us to determine the forecast intervals and elasticity of exchange rates in relation to each other.

Hypothesis 3: since the pandemic had a significant impact on the economies of the countries of the world, it also made appropriate adjustments to the correlations between the RUB / KZT and USD / KZT exchange rates.

\section{Literature Review}

For a long period of time, the issues of the exchange rate, the assessment and analysis of the influence of various factors on it have been considered by many authors. At the same time, various statistical and econometric methods of analysis were used. Most of the works examined the influence of macroeconomic factors on the exchange rates of individual countries. At the same time, there are works of a more global nature, covering studies of several countries.

Thus, Twarowska K. and others (Twarowska, 2000) analyzed the main factors determining the exchange rate of Poland against the euro. The analysis showed that the balance of payments deficit, inflation rate, interest rate and government deficit are the most significant factors influencing the exchange rate..

Sh.Parveen, A.Qayyum and Kh.M. Ismail applied a simple linear regression model with the usual leastorder method (OLS) to analyze the factors affecting the viability of the exchange rate in Pakistan (Sh.Parveen, A.Qayyum and Kh.M. Ismail, 2012). According to the results of the analysis, it was revealed that inflation is the main factor, the second important variable that leads to a greater change in the exchange rate is economic growth, and the order of exports and imports in variations is in the third and fourth positions.

V. Dodonov considered the relationship of the tenge exchange rate with oil prices and the Russian ruble exchange rate, analyzing the dynamics of key items of the balance of payments of Kazakhstan in order to identify the most closely correlated with the tenge exchange rate current transactions and financial account items (V, Dodonov, 2014).

Ramasami R. et al. Evaluated the impact of macroeconomic variables on exchange rates of three different countries using the bootstrapping method. The results showed that psychological factors predominated in economic variables affecting exchange rates (Ramasamy, R., 2015).

G.R. Oganesyan considered the relationship between the ruble exchange rate and key macroeconomic indicators in Russia through statistical and econometric analysis, as a result, confirming the strong dependence of the ruble exchange rate on oil prices (G.R. Oganesyan, 2016).

Vidyavati, B. et al. Assessed the main macroeconomic indicators affecting the exchange rate. The analysis revealed the presence of a negative relationship between GDP, inflation, interest rate and external debt with the exchange rate (Vidyavathi, B., 2016).

Sheetal Maurya examines the impact of various economic variables on the exchange rate of India's national currency against the US dollar. The analysis revealed a close relationship between imports and the exchange rate between the rupee and the US dollar (Sheetal, 2017).

During a pandemic, the issue of the exchange rate is also of interest to various authors. In particular, studies by some authors show that the effectiveness of foreign exchange markets is difficult to assess (Katusiime et al., 2015), and it is quite difficult to identify any clear pattern of changes and the effectiveness of exchange rates, but it can be tracked especially during crisis situations (Levich et al. al., 2019). The authors also investigated the impact of the Covid-19 pandemic on exchange rates in Turkey, the results of which showed that the emergence of new foci of the disease causes uncertainty in the economy, which leads to significant fluctuations in the exchange rate of the Turkish national currency against other currencies of countries (Eda Dineri et al. , 2020).

Hoffman et al. stated in their study that the Covid-19 epidemic has enlarged and complicated the markets of emerging market economies, especially in developing countries (Hoffman et al., 2020). In his study, he found that the dynamics of capital flows during the pandemic increased the negative impact of high credit margins on domestic exchange rates (Kouma, H., 2020).

F.Aslam et al. Applied multifractal analysis of fluctuations without a trend (MF-DFA) to assess the performance of foreign exchange markets during the initial and ongoing period of COVID-19, which brought down the global financial markets (F.Aslam, 2020). At the same time, the issues of mutual influence of cur- 
rency pairs that have a powerful impact on the development of the country's economy have not yet been considered. This is especially true for Kazakhstan.

\section{Methods}

Regression analysis was used as the main method of analysis, to estimate the parameters $\alpha$ and $\beta$ of which the least squares method (OLS) was used. The elasticity coefficients and confidence intervals of the currency forecast were also estimated. In order to compare the behavior of currency pairs before the pandemic and as a result of the impact of COVID-19, the time period for the study was divided into two parts: until 2019 and from 2019 to the present. Regression analysis was carried out for each interval separately.

Regression analysis is used to visualize the form of the relationship between the studied economic indicators. The set of points of effective and factorial features forms a correlation field, on the basis of which it is possible to put forward a hypothesis about the presence of a linear relationship between all possible values of $\mathrm{X}$ and Y (I.M.Borkovskaya et al., 2018)

The estimated regression equation is formed as follows:

where: $\varepsilon_{\mathrm{i}}-$ observed error estimates;

$$
y=\beta x+\alpha+\varepsilon_{i}
$$

$\alpha$ и $\beta$-parameters of the regression model to be determined.

In turn, the LSM system can be written as follows:

$$
S=\sum_{i=1}^{n}\left(y_{i}-y_{i}^{*}\right)^{2} \rightarrow \min
$$

In this case, the system of normal equations will have the following form:

$$
\left\{\begin{array}{c}
\alpha n+\beta \sum x=\sum y \\
\alpha \sum x+\beta \sum x^{2}=\sum y x
\end{array}\right.
$$

Many authors use regression coefficients in the scoring equation to directly assess the influence of factors on an outcome trait (Anusha, 2020). However, in our opinion, it is undesirable to do this because in most cases there is a difference in the units of measurement of the effective indicator $\mathrm{y}$ and the factor attribute $\mathrm{x}$, and there is also an error. For these purposes, it is most convenient and significant to estimate the elasticity coefficients, which show how many percent, on average, in the aggregate, the result $\mathrm{y}$ will change from its average value when the factor $\mathrm{x}$ changes by $1 \%$ from its average value. Thus, the coefficient of elasticity is estimated as follows:

$$
E=\beta \frac{\bar{x}}{\bar{y}}
$$

The quality of the regression equation in our case was estimated by estimating the error of the absolute approximation:

$$
\bar{A}=\frac{\sum\left|y_{i}-y_{x}\right| / y_{i}}{n} 100 \%
$$

If the approximation error is within 5\% -7\%, then this indicates a good fit of the regression equation to the original data. The t-test and the F-test were also evaluated to assess the significance of the obtained regressions. The data for the models was taken from Bloomberg.

\section{Results}

As mentioned earlier, a regression model was applied to assess the mutual influence of the RUB / KZT and USD / KZT currency pairs. To begin with, let's estimate the degree of interdependence in the period before the pandemic (model A). Based on the calculations, the following system of equations was obtained:

$$
\left\{\begin{array}{l}
56 \alpha+287.634 \beta=18468.57 \\
287.634 \alpha+1553.591 \beta=99808.541
\end{array}\right.
$$

From this system, we calculate the empirical regression coefficients, which are equal to $\beta=64.9236$ and $\alpha=-3.6721$.

As a result, the empirical regression equation has the following form: $\mathrm{y}=64.9236 \mathrm{x}-3.6721$

The coefficient of elasticity in this case will be equal to:

$$
E=64.924 \frac{5.136}{329.796}=1.011
$$

Since the elasticity coefficient is higher than 1, the RUB / KZT currency pair significantly affects the USD / KZT currency pair, that is, if the tenge / ruble exchange rate changes by $1 \%$, the tenge / US dollar exchange rate will change by more than $1 \%$. 
Let us estimate the approximation error:

$$
\bar{A}=\frac{2.401}{56} 100 \%=4.29 \%
$$

Based on the data obtained, the calculated values deviate from the actual values on average by $4.29 \%$, which is less than $7 \%$, which means that the resulting equation is statistically significant and can be used as a regression. The correlation index is:

$$
\operatorname{corr}=\sqrt{\frac{321254.639}{338135.26}}=0.975
$$

The correlation index shows a high degree of relationship between the exchange rates of the ruble and the US dollar against the tenge, almost 1.

Calculate t-tests using empirical regression coefficients:

$$
t_{\alpha}=\frac{-3.672}{10.667}=0.34 \quad t_{\beta}=\frac{64.924}{2.025}=32.06
$$

Since $0.34<2$, we accept the hypothesis that this coefficient $\alpha$ is equal to zero, that is, in this case, the coefficient $\alpha$ can be neglected.

Since 32.06>2, the statistical significance of the regression coefficient $\beta$ is confirmed.

Let us estimate the confidence interval for the regression coefficients with a probability of $95 \%$ :

$-3.672-2 * 10.667$

$-3.672+2 * 10.667$

Therefore, it is possible to assert with $95 \%$ probability that $\alpha$ will be within the limits $(-25.006 ; 17.662)$.

$64.92-2 * 2.025$

$64.92+2 * 2.025$

Therefore, it is possible to assert with $95 \%$ probability that $\beta$ will be in the range $(60.873 ; 68.974)$.

Thus, according to the model for assessing the mutual influence of exchange rates in the period before the pandemic, the results are presented in Table 1 .

Table 1. Parameters of model A (before the pandemic)

\begin{tabular}{|l|c|c|c|c|c|c|c|c|}
\hline $\begin{array}{l}\text { Source of } \\
\text { variation }\end{array}$ & $\begin{array}{c}\text { Sum of } \\
\text { squares }\end{array}$ & $\begin{array}{c}\text { Number of de- } \\
\text { grees of freedom }\end{array}$ & $\begin{array}{c}\text { Elasticity } \\
\text { coefficient }\end{array}$ & $\begin{array}{c}\text { Correla- } \\
\text { tion index }\end{array}$ & t-criteria & F-criteria & $\mathrm{R}^{2}$ & $\begin{array}{c}\text { Approximation } \\
\text { error }\end{array}$ \\
\hline $\begin{array}{l}\text { Model (ex- } \\
\text { plained) }\end{array}$ & 321254.639 & 1 & 1.011 & 0.975 & $\begin{array}{c}0.34 \\
32.06\end{array}$ & $\begin{array}{c}1027.67 \\
3\end{array}$ & 0.9501 & 4.29 \\
\hline Residual & 16880.62 & 54 & - & - & - & 1 & - & - \\
\hline General & 338135.26 & $56-1$ & - & - & - & - & - & - \\
\hline
\end{tabular}

Model A data allows you to build a scatter diagram (Figure 1).

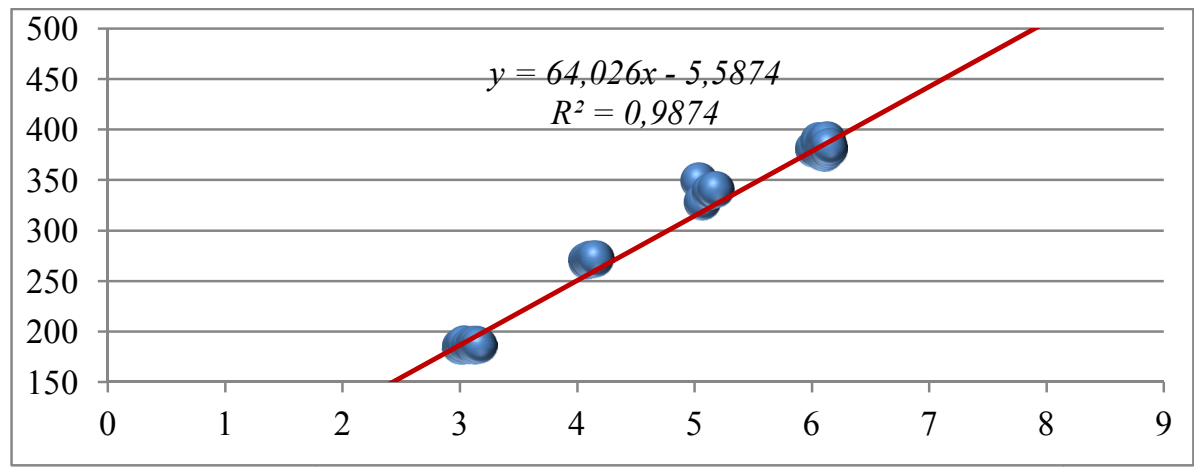

Figure 1. Diagram of the scattering of the mutual influence of the exchange rates of the ruble and the US dollar against the tenge before the pandemic (model A) 
Let us estimate the parameters of the regression model reflecting the mutual influence of exchange rates as a result of the impact of COVID-19 on the financial markets of Russia, the United States and Kazakhstan (model B). The data for the calculations were also taken from Bloomberg.

For data on the RUB / KZT and USD / KZT exchange rates taken during the pandemic, the system of equations will be as follows:

$$
\left\{\begin{array}{c}
41 \alpha+227.78 \beta=17488.79 \\
227.78 \alpha+1265.674 \beta=97156.317
\end{array}\right.
$$

The solution of this system allows you to obtain the regression coefficients: $\alpha=543.796$ и $\beta=$ 21.103 , as a result, the empirical regression equation is: $\mathrm{y}=-21.103 \mathrm{x}+543.7961$

The coefficient of elasticity is:

$$
E=-21.103 \frac{5.556}{426.556}=-0.275
$$

Since the elasticity coefficient is lower than 1, the RUB / KZT currency pair does not significantly affect the USD / KZT currency pair, that is, if the tenge / ruble exchange rate changes by $1 \%$, the tenge / US dollar exchange rate will change by less than $1 \%$.

Let us estimate the approximation error:

$$
\bar{A}=\frac{0.207}{41} 100 \%=0.51 \%
$$

Based on the data obtained, the calculated values deviate from the actual values on average by $0.51 \%$, which is less than $7 \%$, which means that the obtained equation is statistically significant and can be used as a regression. The correlation index is:

$$
\operatorname{corr}=\sqrt{\frac{96.554}{374.75}}=0.508
$$

The correlation index shows a low, but significant degree of relationship between the ruble and the US dollar against the tenge, slightly above 0.5 .

Calculate t-tests using empirical regression coefficients:

$$
t_{\alpha}=\frac{543.796}{31.869}=17.06 \quad t_{\beta}=\frac{-21.103}{5.736}=3.68
$$

Since $17.06>2.329$, the statistical significance of the regression coefficient $\alpha$ is confirmed.

Since $3.68>2.329$, the statistical significance of the regression coefficient $\beta$ is confirmed.

Let us estimate the confidence interval for the regression coefficients with a probability of $95 \%$ :

$543.796-2.329 * 31.869$

$543.796+2.329 * 31.869$

Therefore, it is possible to assert with $95 \%$ probability that $\alpha$ will be within the limits (469.573;618.019).

$-21.1-2.329 * 5.736$

$-21.1+2.329 * 5.736$

Therefore, it is possible to assert with $95 \%$ probability that $\beta$ will be in the range $(-34.462 ;-7.744)$.

Thus, according to the model for assessing the mutual influence of exchange rates during the period of a pandemic, the results are presented in Table 2 ..

Table 2. Parameters of model B (during a pandemic)

\begin{tabular}{|l|c|c|c|c|c|c|c|c|}
\hline $\begin{array}{l}\text { Source of } \\
\text { variation }\end{array}$ & $\begin{array}{c}\text { Sum of } \\
\text { squares }\end{array}$ & $\begin{array}{c}\text { Number of degrees } \\
\text { of freedom }\end{array}$ & $\begin{array}{c}\text { Elasticity } \\
\text { coefficient }\end{array}$ & $\begin{array}{c}\text { Correlation } \\
\text { index }\end{array}$ & t-criteria & F- criteria & $\mathrm{R}^{2}$ & $\begin{array}{c}\text { Approxim } \\
\text { ation error }\end{array}$ \\
\hline $\begin{array}{l}\text { Model } \\
\text { (explained) }\end{array}$ & 96.554 & 1 & -0.275 & -0.5076 & $\begin{array}{c}17.06 \\
3.68\end{array}$ & 13.536 & 0.2577 & 0.51 \\
\hline Residual & 278.19 & 39 & - & - & - & 1 & - & - \\
\hline General & 374.75 & $41-1$ & - & - & - & - & - & - \\
\hline
\end{tabular}


Model B data allow you to build a scatter diagram (Figure 2).

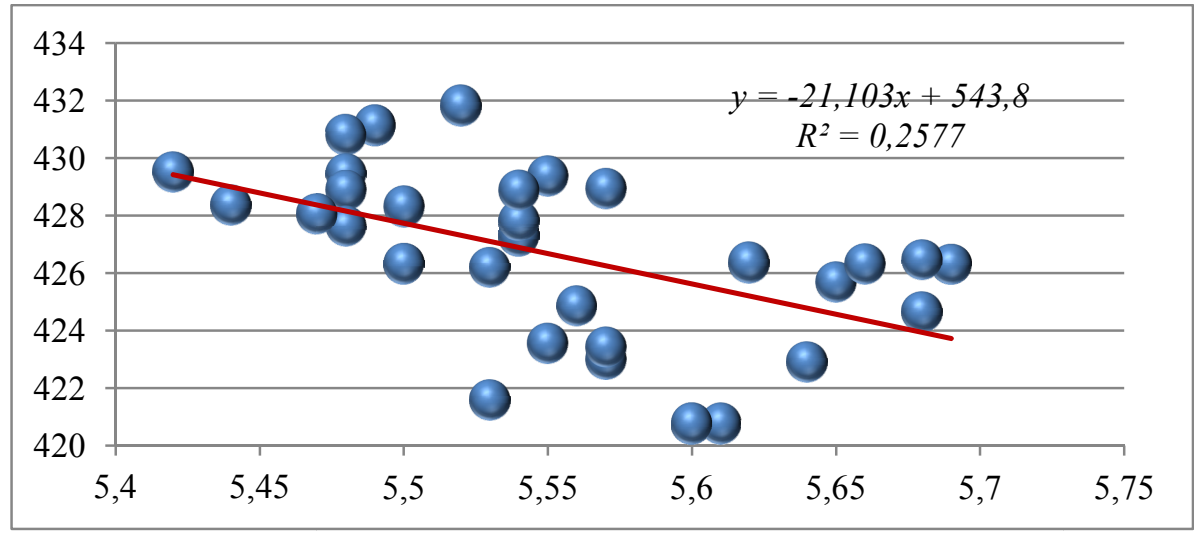

Figure 1. Diagram of the scattering of the mutual influence of the exchange rates of the ruble and the US dollar against the tenge during a pandemic (model B)

Note - compiled by the authors on the basis of calculations and Bloomberg data

Thus, on the basis of regression models, data were obtained on the mutual influence of the RUB / KZT and USD / KZT currency pairs before the COVID-19 pandemic and during the period of its action and impact on the financial markets of the countries of the world.

\section{Discussions}

The analysis shows that the pandemic has made its own adjustments in the exchange rates of the tenge against the ruble and the US dollar, as well as in the degree of their interdependence. In Figure 2, the change in the influence of currency pairs in model B is obvious.

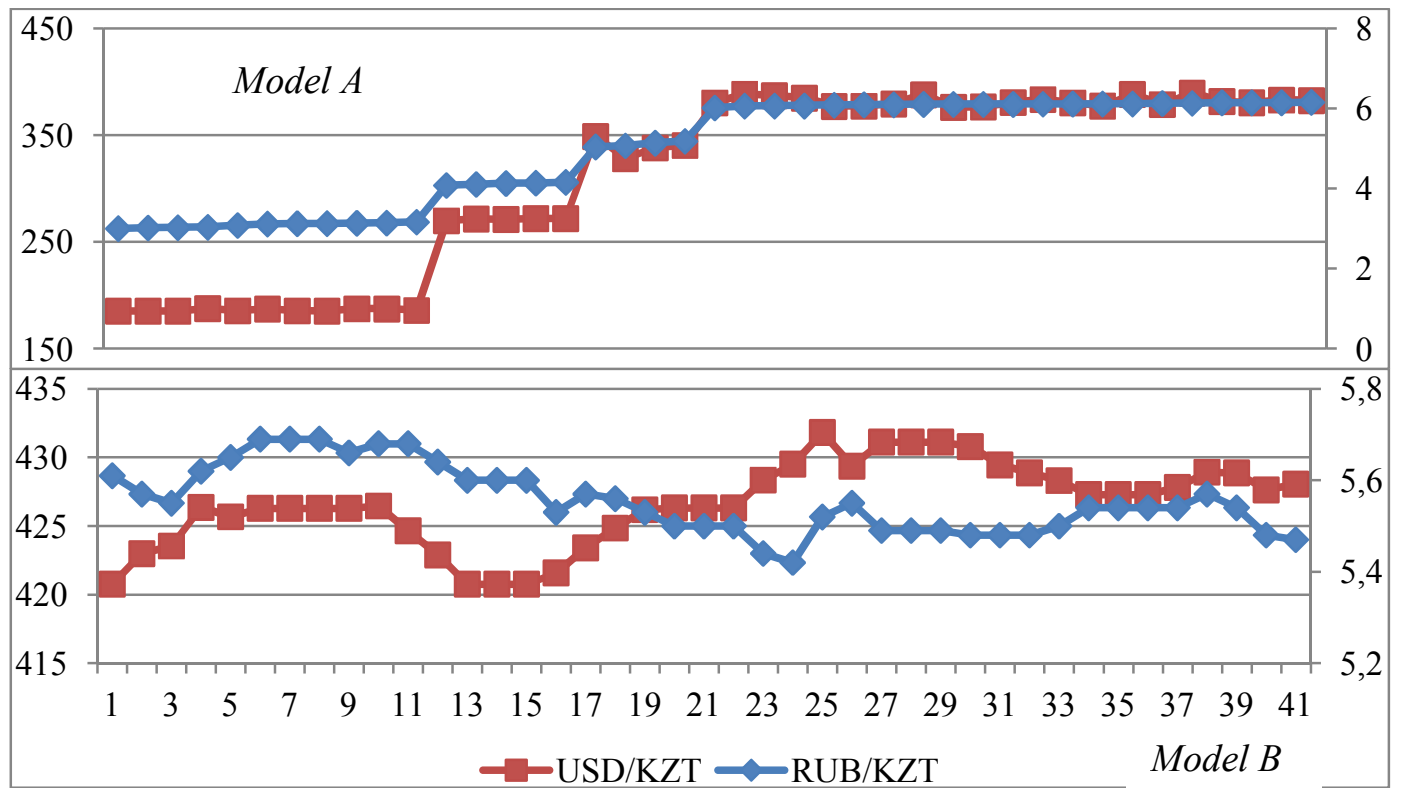

Figure 2. Interaction of the exchange rates of the ruble and the US dollar against the tenge before the pandemic and during the COVID-19 period

Note - compiled by the authors on the basis of calculations and Bloomberg data

The results of evaluating model A show that in the studied situation, $95.01 \%$ of the total variability in USD / KZT is explained by the change in RUB / KZT. It was also found that the parameters of the model are statistically significant. In the period before the pandemic, the impact of RUB / KZT on USD / KZT was much more significant. Thus, the assessment of the dependence of these currency pairs showed that if the exchange rate of the tenge against the ruble changes by $1 \%$, the exchange rate of the tenge against the US 
dollar will change by more than $1 \%$. The obtained estimates of the regression equation allow us to determine the forecast boundaries in the period before the pandemic. So, if the tenge / ruble rate were 6 , then the tenge / US dollar rate would be in the range from 344.66 to 427.08 tenge and with a $95 \%$ probability would not go beyond the specified limits.

However, the impact of the pandemic on the dependence of exchange rates has led to certain changes. If earlier the growth of the exchange rate of the tenge against the ruble led to an increase in the exchange rate of the tenge against the US dollar, now the RUB / KZT currency pair does not significantly affect the USD / KZT currency pair, that is, if the exchange rate of the tenge against the ruble increases by $1 \%$, the exchange rate tenge against the US dollar will decrease by less than 1\%. Thus, with a unit value of 6 tenge, the US dollar will be in the range from 408.52 to 425.83 tenge and with a $95 \%$ probability it will not go beyond these limits.

At the same time, the degree of dependence of these exchange rates decreases. If before the pandemic the correlation coefficient was 0.97 , that is, it showed an almost absolute, moreover, positive correlation, then as a result of the influence of the pandemic, the correlation coefficient decreased to 0.5 , and with the reflection of the inverse relationship.

\section{Conclusions}

The results obtained allow us to confirm the hypotheses put forward earlier. In particular, if we consider the tenge as a base of assessment, then based on the study of the correlation between the tenge and the ruble and the tenge against the US dollar, one can estimate the degree of interdependence of the RUB / KZT and USD / KZT exchange rates. Indeed, the assessment showed the ruble's dependence on the US dollar.

The presence of a relationship between exchange rates allows you to determine the forecast intervals and elasticity of exchange rates in relation to each other. As a result of the analysis, it was determined how the exchange rate of the tenge against the US dollar will change if the ruble rate is 6 tenge in the period before the pandemic and as a result of its impact on the financial market of Kazakhstan.

Since the pandemic had a significant impact on the economies of the countries of the world, it made corresponding adjustments to the correlations of the RUB / KZT and USD / KZT exchange rates. As the analysis has shown, the correlations between these exchange rates have changed significantly: the dependence has become weaker and negative.

Thus, the analysis performed allows us to show that the impact of the pandemic on exchange rates is ambiguous, which weakens the degree of mutual influence of exchange rates on each other, even in closely interacting countries. This analysis requires further research on the factors that had such an impact on the relationship between the RUB / KZT and USD / KZT exchange rates.

\section{References}

Anusha Illukkumbura (2020) Introduction to Regression Analysis Independently Published, 122 p. ISBN $979-$ 8649727648.

Borkovskaya, I.M. (2018). Ekonometrika i ekonomiko-matematicheskie metody i modeli: ucheb.-metod. posobie dlia studentov ekonomicheskikh spetsialnostei zaochnoi formy obucheniia. Minsk: BGTU [in Russian].

Dodonov, V. (2014). Osnovnyye faktory, opredelyayushchie dinamiku kursa natsionalnoi valyuty Kazakhstana. Kazakhski ekonomicheski vestnik, 4, 46-60 [in Russian].

Eda Dineri et al. (2020) The COVID-19 Process and the Exchange Rate Relation: An Application on Turkey Retrieved from https://www.researchgate.net/publication/343276624_The_COVID-19_Process_and_the_Exchange_Rate Relation_An_Application on Turkey

F.Aslam et al. (2020) On the efficiency of foreign exchange markets in times of the COVID-19 pandemic. Technological Forecasting \& Social Change, 161, 1202612

Hofmann, B., Shim, I. and Shin, H.S. (2020). Emerging Market Economy Exchange Rates And Local Currency Bond Markets Amid The Covid-19 Pandemic, BIS Bulletin, 5

Katusiime, L., Shamsuddin, A. \& Agbola, F. W. (2015). Foreign exchange market efficiency and profitability of trading rules: Evidence from a developing country. International Review of Economics \& Finance, 35, 315-332.

Kouma, H. (2020). Assessing the Economic and Financial Fallout from COVID-19; Implications for Macroprudential Policy. Retrieved from https://papers.ssrn.com/sol3/papers.cfm?abstract_id=3603625 accessed on July 05 2020/

Levich, R., Conlon, T. \& Poti, V. (2019). Measuring excess-predictability of asset returns and market efficiency over time. Economics Letters, 175, 92-96.

Oganesyan, G.R. (2016). Analiz vzaimosviazi valyutnogo kursa s klyuchevymi makroekonomicheskimi pokazateliami v Rossii. Vestnik Instituta ekonomiki RAN, 6, 184-197 [in Russian]. 
Ramasamy, R., \& Abar, S. K. (2015). Influence of Macroeconomic Variables on Exchange Rates.Journal of Economics, Business \& Management, 3(2), 276-281. Retrieved from https://doi.org /10.7763/JOEBM.2015. V3.194 https://doi.org/10.7763/JOEBM.2015.V3.194

Sh.Parveen, A.Qayyum и Kh.M. Ismail (2012) Analysis of the Factors Affecting Exchange Rate Variability in Pakistan.Academic Research International, 2(3), 670-674.

Sheetal Maurya (2017) Factors affecting Exchange Rate and its Impact on Economy of India. Asian Journal of Research in Business Economics and Management, 7 (8), 324-347.

Twarowska, K. (2000). Analysis of factors affectng fluctuations in the exchange rate of Polish Zloty against Euro. Toknowpress. Retrieved from www.toknowpress.net/ISBN/978-961- 6914-09-3/papers/ML14-652.pdf

Vidyavathi, B., Keerti, K., \& Pooja, A. (2016). A Study on macro economic indicators and their impact on exchange rates. International Journal of Engineering and Management Studies, 7(3), 160-169

\section{Э.А. Рузиева, А.М. Нургалиева, З.К. Есымханова, Л.А. Чайковская \\ RUB / KZT және USD / KZT айырбастау бағамдарының өзара әсерін модельдеу және талдау: пандемияға дейінгі кезең және COVID-19 әсерінің нәтижесі ретінде}

\section{Аңдатпа}

Maқ̧cambl: COVID-19 пандемиясына дейін және оның Қазақстанның қаржы нарығына әсері кезеңінде теңгеге қатысты рубль мен АҚШ долларының айырбас бағамдарының өзара тәуелділігі мен өзара әсерін салыстырмалы бағалауды жүзеге асыру.

Әдістері: Зерттеудің негізгі әдістері-регрессиялық модельдеу, ең аз квадраттар әдісі, әртүрлі факторлардың елдердің валюта бағамдарына әсерін бағалаған әртүрлі авторлардың теориялық және әдіснамалық тәсілдерін жалпылау және талдау әдістері.

Қорытынды: Пандемия рубль мен АҚШ долларының теңгеге қатысты айырбас бағамдарының қалыптасуына белгісіздік әкелді. Covid-19 әсерінің нәтижесінде пандемияға дейін болған RUB / KZT және USD / KZT валюта жұптары арасындағы күшті тікелей тәуелділік теріс және әлсіз корреляциялық тәуелділікпен алмастырылды.

Тұжырымдама: Пандемияның рубльдің теңгеге және доллардың теңгеге айырбастау бағамдарына әсері бір мәнді емес, бұл тіпті бір-бірімен тығыз өзара іс-қимыл жасайтын елдердің өзінде рубль мен АҚШ долларының айырбас кросс-бағамдарының өзара әсер ету дәрежесін төмендетеді. Рубль / теңге және доллар / теңге валюта жұптарының өзара тәуелділігінің осындай өзгеруіне ықпал еткен факторларды анықтау үшін одан әрі зерттеулерді талап етеді.

Kiлm сөздер: валюта бағамы, бағамдардың корреляциясы, болжам аралықтары, пандемия, регрессиялық талдау, валюта бағамының құбылмалылығы, бағамның икемділігі.

\section{Э.А. Рузиева, А.М. Нургалиева, З.К. Есымханова, Л.А. Чайковская}

\section{Моделирование и анализ взаимовлияния обменных курсов RUB / KZT и USD / KZT: период до пандемии и как результат воздействия COVID-19}

\section{Аннотация}

Цель: Осуществить сравнительную оценку взаимозависимости и взаимовлияния обменных курсов рубля и доллара США по отношению к тенге до пандемии COVID-19 и в период ее воздействия на финансовый рынок Казахстана.

Memoдbl: Основными методами исследования выступают регрессионное моделирование, методы наименьших квадратов, анализа и обобщения теоретико-методологических подходов различных авторов, проводивших оценку влияния различных факторов на валютные курсы стран.

Результаты: Пандемия COVID-19 внесла неопределенность в формирование обменных курсов рубля и доллара США по отношению к тенге. Сильная прямая зависимость между валютными парами RUB / KZT и USD / KZT, которая существовала до пандемии, в результате воздействия COVID-19, сменилась отрицательной и более слабой корреляционной зависимостью.

Bblводыl: Влияние пандемии на обменные курсы рубля к тенге и доллара к тенге неоднозначно, что снижает степень взаимного влияния обменных кросс-курсов рубля и доллара США даже в странах, тесно взаимодействующих друг с другом. Требуются дальнейшие исследования для выявления факторов, которые способствовали такому изменению взаимозависимости валютных пар рубль / тенге и доллар / тенге. 
Ключевые слова: обменный курс, корреляция курсов, интервалы прогнозов, пандемия, регрессионный анализ, волатильность обменного курса, эластичность курса.

\section{References}

Anusha Illukkumbura. Introduction to Regression Analysis Independently Published, 2020. - 122 p. - ISBN 9798649727648.

Eda Dineri et al. The COVID-19 Process and the Exchange Rate Relation: An Application on Turkey (https://www.researchgate.net/publication/343276624_The_COVID-19_Process_and_the_Exchange_Rate Relation_An_Application_on_Turkey)

F.Aslam et al. On the efficiency of foreign exchange markets in times of the COVID-19 pandemic// Technological Forecasting \& Social Change, 2020. - №161. - 1202612

Hofmann, B., Shim, I. and Shin, H.S. Emerging Market Economy Exchange Rates And Local Currency Bond Markets Amid The Covid-19 Pandemic//BIS Bulletin, 2020.- No. 5. - pp. 7.

Katusiime, L., Shamsuddin, A. \& Agbola, F. W. Foreign exchange market efficiency and profitability of trading rules: Evidence from a developing country//International Review of Economics \& Finance, 2015.- №35. -pp. 315-332.

Kouma, H. Assessing the Economic and Financial Fallout from COVID-19; Implications for Macroprudential Policy. 2020. (https://papers.ssrn.com/sol3/papers.cfm?abstract_id=3603625 accessed on July 05 2020)

Levich, R., Conlon, T. \& Poti, V. Measuring excess-predictability of asset returns and market efficiency over time//Economics Letters, 2019.- №175. - pp. 92-96.

Ramasamy, R., \& Abar, S. K. Influence of Macroeconomic Variables on Exchange Rates//Journal of Economics, Business \& Management, 2015.- 3(2). - pp.276-281. (https://doi.org /10.7763/JOEBM.2015. V3.194 https://doi.org/10.7763/JOEBM.2015.V3.194)

Sh.Parveen, A.Qayyum и Kh.M. Ismail Analysis of the Factors Affecting Exchange Rate Variability in Pakistan//Academic Research International, 2012. - Vol. 2, No. 3. - pp.670-674.

Sheetal Maurya Factors affecting Exchange Rate and its Impact on Economy of India//Asian Journal of Research in Business Economics and Management 2017. - Vol. 7, No. 8. - pp. 324-347.

Twarowska, K. Analysis of factors affectng fluctuations in the exchange rate of Polish Zloty against Euro (www.toknowpress.net/ISBN/978-961- 6914-09-3/papers/ML14-652.pdf)

Vidyavathi, B., Keerti, K., \& Pooja, A. A Study on macro economic indicators and their impact on exchange rates/International Journal of Engineering and Management Studies, 2016.- 7(3). - pp.160-169

V.Dodonov Osnovnyye faktory, opredelyayushchiye dinamiku kursa natsional'noy valyuty Kazakhstana//Kazakhskiy ekonomicheskiy vestnik, 2014. - №4. - S.46-60.

Oganesyan G.R. Analiz vzaimosvyazi valyutnogo kursa s klyuchevymi makroekonomicheskimi pokazatelyami v Rossii // Vestnik Instituta ekonomiki RAN. 2016. - №6. - S. 184-197.

Borkovskaya I. M. Ekonometrika i ekonomiko-matematicheskie metody i modeli : uchebno-metodicheskoe posobie dlya studentov ekonomicheskikh spetsialnostei zaochnoi formy obucheniia / I. M. Borkovskaya [i dr.]. - Minsk : BGTU, 2018. - 129 s. 